\title{
Immunoglobulins and antibody to Loa loa in Nigerians with endomyocardial fibrosis and other heart diseases
}

\author{
R. Carlisle, E. O. Ogunba, H. McFarlane, ${ }^{1}$ O. A. Onayemi, and V. O. Oyeleye \\ From the Departments of Medicine, Microbiology, and Chemical Pathology, \\ University of Ibadan, Nigeria
}

Sera from 83 patients with organic heart disease attending the cardiac clinic, University College Hospital, Ibadan, were examined for $\operatorname{Ig} G, \operatorname{Ig} A$, and $\operatorname{Ig} M$ concentration and, in 34 cases, for antibody to Loa loa microfilariae. Immunoglobulin levels were all raised, but so far there was no statistically significant difference between disease groups diagnosed as endomyocardial fibrosis and as other heart diseases. Antibody to Loa loa was detected in a small number of patients with all forms of heart disease.

It is now widely accepted that neither malnutrition nor consumption of plantains (Ojo, 1970) is crucial in the aetiology of endomyocardial fibrosis. Current theories incriminate filarial infection (Gerbaux, Garin, and Lenegre, 1957) or malaria or streptococcal infection (Shaper, 1966) but neither of these has been substantiated. Autoimmune reactions with heart tissue as antigens have been studied in patients with recognized endomyocardial fibrosis using immunofluorescence and other techniques by Geld et al. (1966) and by Shaper et al. (1967). Ive et al. (1967) reported that patients with endomyocardial fibrosis showed a 64 per cent positive skin test to cattle filarial antigen while the controls showed only a 36 per cent positive skin test. These observations prompted the present study which is concerned with serum immunoglobulin determinations and precipitin antibodies to Loa loa antigen.

\section{Subjects and methods}

Nigerian patients attending the cardiac clinic of the Department of Medicine, University College Hospital, Ibadan, were studied. The group consisted of 28 patients with endomyocardial fibrosis and 55 patients with other organic heart disease comprising 20 with hypertensive heart failure, Io with rheumatic heart disease, 6 with myocardial disease, 5 with annular ventricular aneurysm, 3 with pericardial disease, 3 with undifferentiated

Received 13 August 1971.

1 Present address: Chemical Pathology Department, Williamson Building, University of Manchester. mitral incompetence, 3 with cor pulmonale, 2 with congenital heart disease, and I each with ischaemic heart disease, anaemic heart failure, and infective endocarditis.

The diagnosis was made in 54 patients by clinical findings including chest $x$-ray, 13-lead electrocardiogram, and, where indicated, blood count, laboratory tests for syphilis, antistreptolysin $\mathrm{O}$ titre, and blood culture. In 20 patients it was necessary to perform cardiac catheterization with recording of pressure, and frequently angiography of the affected ventricles, in addition to clinical examination. The diagnosis was based on morbid anatomical findings in 9 patients.

The male/female ratio for all the groups combined was about $\mathrm{I} \cdot 5$ to $\mathrm{I}$. The patients with endomyocardial fibrosis had a mean age of 28 years while the mean age for the other groups was between 35 and 50 years. The majority were resident around Ibadan and belonged to a semirural community of low socioeconomic status and had symptoms of sufficient severity to cause hospital attendance in spite of the usual preference for 'native healers'. Those patients for whom a diagnosis of endomyocardial fibrosis was uncertain were not included in this study.

Immunoglobulins were determined by the single radial diffusion technique of Mancini, Carbonara, and Heremans (1965).

The microfilaria loa were obtained from blood by the method of Jayewardene and Wijayaratnam (I968) and washed several times with phosphate buffered saline, $p \mathrm{H} \mathrm{7.4}$, to remove all traces of blood. The parasites were homogenized by ultrasonic vibrations using the MSE sonicator, then centrifuged at $8000 \mathrm{rpm}$ for 30 minutes. The clear supernatant was used as microfilarial antigen. A control extract from normal blood was similarly prepared and this gave no precipitation lines with 
positive sera. The total protein concentration of this microfilarial antigen was $19 \mathrm{mg} / \mathrm{ml}$ as determined by the biuret method of Gornall, Bardawill, and David (1949).

\section{Results}

The serum immunoglobulin results are summarized in Table $\mathrm{I}$. The serum IgG levels are raised for all the groups and there is no significant difference between them. Patients with rheumatic heart disease had higher mean levels of serum IgA than any other groups, though the difference was not statistically significant. The highest serum IgM values were obtained in those patients with endomyocardial fibrosis, 2 of these having values of $27 \mathrm{mg} / \mathrm{ml}$ which can be considered as secondary macroglobulinaemia. The pattern

FI G. Histograms of immunoglobulin results.
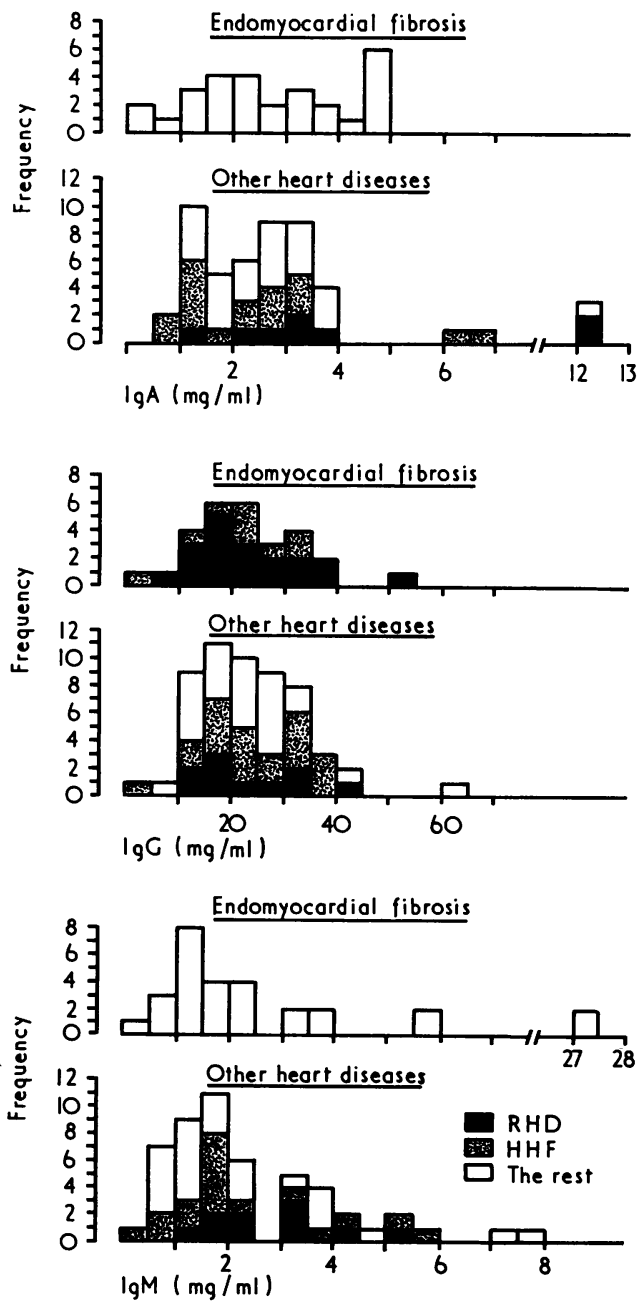

TABLE I Summary of immunoglobulin concentration in patients with organic heart diseases

\begin{tabular}{|c|c|c|c|c|}
\hline $\begin{array}{l}\text { Immunoglobulin } \\
\text { type }(\mathrm{mg} / \mathrm{ml})\end{array}$ & $\begin{array}{l}\text { Endomyocardial } \\
\text { fibrosis }\end{array}$ & $\begin{array}{l}\text { Rheumatic heart } \\
\text { disease }\end{array}$ & $\begin{array}{l}\text { Hypertensive } \\
\text { heart failure }\end{array}$ & The rest \\
\hline \multicolumn{5}{|l|}{$I g G$} \\
\hline Mean & 22.65 & $22 \cdot 90$ & 23.76 & $23 \cdot 10$ \\
\hline SE & $I \cdot 82$ & $2 \cdot 89$ & $2 \cdot$ I I & $2 \cdot 29$ \\
\hline No. & $(28)$ & (I0) & $(20)$ & $(25)$ \\
\hline \multicolumn{5}{|l|}{$\operatorname{Ig} A$} \\
\hline Mean & 2.67 & 5.04 & $2 \cdot 45$ & $2 \cdot 80$ \\
\hline $\begin{array}{l}\text { SE } \\
\text { No. }\end{array}$ & $\begin{array}{l}0.27 \\
(28)\end{array}$ & $(8)$ & $\begin{array}{l}0.38 \\
(18)\end{array}$ & $\begin{array}{l}0.43 \\
(24)\end{array}$ \\
\hline \multicolumn{5}{|l|}{$I g M$} \\
\hline Mean & $3 \cdot 83$ & $2 \cdot 79$ & $2 \cdot 30$ & $2 \cdot 35$ \\
\hline SE & I.24 & 0.38 & 0.36 & 0.38 \\
\hline No. & (28) & (10) & (I7) & (24) \\
\hline
\end{tabular}

SE, standard error. No., number of patients.

of these results is presented in the accompanying histograms (Fig.).

Table 2 shows the results of the precipitin tests for Loa loa antibody in the serum of the patients. Seven out of 3I sera tested gave positive precipitin reactions.

\section{Discussion}

The results show raised serum immunoglobulin levels in all patients with heart disease and the lack of any significant difference between them may be owing to widespread prevalence of protozoal, bacterial, and helminth infections which are also known to cause increased immunoglobulin levels (McFarlane, 1966). Two patients with endomyocardial fibrosis had secondary macroglobulinaemia and there was a tendency towards higher IgM values in this group than in the other groups of patients with heart disease. The significance of this finding is being further investigated. It is interesting that the mean serum IgA in patients with rheumatic heart disease is higher

TABLE 2 Summary of precipitin antibody to Loa loa microfilariae in patients with organic heart disease

\begin{tabular}{lll}
\hline Diagnostic category & $\begin{array}{l}\text { No. of patients } \\
\text { tested }\end{array}$ & $\begin{array}{l}\text { No. of patients } \\
\text { positive }\end{array}$ \\
\hline $\begin{array}{l}\text { Endomyocardial } \\
\text { fibrosis }\end{array}$ & 5 & \\
$\begin{array}{l}\text { Rheumatic heart } \\
\text { disease }\end{array}$ & 7 & 2 \\
$\begin{array}{l}\text { Hypertensive heart } \\
\text { failure }\end{array}$ & Io & 2 \\
The rest & 9 & I \\
\hline
\end{tabular}


than in the other patients though the student ' $t$ ' test was not significant.

Loa loa is the only filarial worm normally parasitic in man and known to have a distribution similar to that of endomyocardial fibrosis in Nigeria (Ive et al., 1967). Though suggestive of no specific role of Loa loa infection, the number of patients' sera tested is too small to arrive at any firm conclusions and those tested could not be titrated nor could they be concentrated because of the amounts of serum available. However, the use of specific filarial antigen and its method of preparation are of obvious importance in narrowing down the range of infectious agents which are possibly involved in the pathogenesis of endomyocardial fibrosis. After the finding of small granulomata in the livers of patients with endomyocardial fibrosis (Osunkoya, Carlisle, and Basile, 1972) it seems that the portal of entry is the gut and not, as with Loa loa, insect bite.

We acknowledge the support of the World Health Organization and are grateful to Dr. Uzodike for collecting the initial serum samples.

\section{References}

Geld, H. van der, Peetoom, F., Somers, K., and Kanyerezi, B. R. (1966). Immunohistological and serological studies in endomyocardial fibrosis. Lancet, 2, 1210 .
Gerbaux, A., Garin, G. P., and Lenegre, J. (1957). Cardiopathie et filariose. Bulletins et Mémoires de la Société Médicale des Hôpitaux de Paris, 73, 873.

Gornall, A. G., Bardawill, C. J., and David, M. M. (1949). Determination of serum proteins by means of the biuret reaction. Fournal of Biological Chemistry, 177, 75I.

Ive, F. A., Willis, A. J. P., Ikeme, A. C., and Brockington, I. F. (1967). Endomyocardial fibrosis and filariasis. Quarterly fournal of Medicine, 36, 495.

Jayewardene, L. G., and Wijayaratnam, Y. (1968). The fluorescent antibody test in the serological diagnosis of the causative organisms of tropical eosinophilia and filariasis. Fournal of Helminthology, 42, 57.

McFarlane, H. (1966). Immunoglobulins in Nigerians. Lancet, 2, 445.

Mancini, G., Carbonara, A. O., and Heremans, J. F. (1965). Immunochemical quantitation of antigens by single radial immunodiffusion. Immunochemistry, 2, 235.

Ojo, G. O. (I970). The pathogenesis of endomyocardial fibrosis. The question of 5-hydroxytryptamine. British Heart fournal, 32, 67I.

Osunkoya, B. O., Carlisle, R., and Basile, U. (1972). Histopathology of extracardiac tissues in endomyocardial fibrosis. African Fournal of Medical Science. In the press.

Shaper, A. G. (1966). Endomyocardial fibrosis and rheumatic heart-disease. Lancet, I, 639.

Shaper, A. G., Kaplan, M. H., Foster, W. D., Macintosh, D. M., and Wilks, N. E. (1967). Immunological studies in endomyocardial fibrosis and other forms of heart-disease in the tropics. Lancet, I, 598.

Requests for reprints to Dr. H. McFarlane, Chemical Pathology Department, Williamson Building, University of Manchester, Brunswick Street, Manchester Mr3 9PL. 